\title{
Recombinant Plant Engineering for Immunotherapeutic Production
}

\author{
Ankit Singh ${ }^{1}$ - Gurminder Kaur ${ }^{2} \cdot$ Sanchita Singh $^{3} \cdot$ Neetu Singh $^{4} \cdot$ Gauri Saxena ${ }^{5}$. \\ Praveen C. Verma $^{3}$
}

Published online: 16 October 2017

(C) Springer International Publishing AG 2017

\begin{abstract}
Purpose of Review The requirement for large quantities of therapeutic proteins has fueled a great interest in the production of recombinant proteins in plant bioreactors. The vaccines and bio-therapeutic protein production in plants hold the promise of significantly lowering the cost of manufacturing life-saving drugs. This review will reflect the current status and challenges that the molecular farming platform faces becoming a strategic solution for the development of low-cost bio-therapeutics for developing countries.

Recent Findings Different plant parts have been successfully identified as suitable expression systems for the commercial production of therapeutic proteins for some human and animal diseases ranging from common cold to AIDS. The processed therapeutics from such sources are devoid of any toxic components. The large-scale cultivation of these transgenic plants would be possible anywhere in the world including
\end{abstract}

This article is part of the Topical Collection on Enhancing Agricultural Production

Praveen C. Verma

praveencverma@nbri.res.in; praveencverma@yahoo.com

1 Department of Biosciences, Jamia Millia Islamia University, New Delhi 110025, India

2 Amity Institute of Biotechnology, Amity University Uttar Pradesh, Sector 125, Noida 201303, India

3 Genetics and Plant Molecular Biology Division, CSIR-National Botanical Research Institute, Rana Pratap Marg, Lucknow, U.P 226001, India

4 Instrumentation Research Facility, Jawahar Lal Nehru University, New Delhi 110067, India

5 Department of Botany, University of Lucknow, Lucknow 226001, India developing countries, which lack sophisticated drug manufacturing units. A couple of such commercially generated products have already hit the market with success. Newer methods using suitable plant viruses and recombinant gene expression systems have already been devised for producing therapeutic proteins and peptides.

Summary Plants are promising bio-factories for therapeutic protein production because of their several advantages over the other expression systems especially the advanced mechanisms for protein synthesis and post-translational modification which are very much similar to animal cells. Plant biotechnologists are much attracted to the bio-farming because of its flexibility, scalability, low manufacturing cost, as well as the lack of risk of toxic or pathogenic contamination. A number of projects on bio-farming are designed and are at various developmental stages but have not yet become available to the pharmaceutical industry. Therefore, we need further advancement in the optimization of lab protocols for up-scaling the production of such therapeutics at commercial level with a promise to offer their best clinical use.

Keywords Plant-based vaccines · Molecular farming · Therapeutic proteins · Plantibodies · Immunotherapeutics · Supplements and effector molecules

\section{Introduction}

The costly and limited accessibility of vaccines and other therapeutic proteins in remote, poor regions of developing countries continues to prevent essential help to needy children. It is a disturbing fact that routine preventable infectious diseases remain a leading source of childhood mortality in the developing world today. In recent years, genetic engineering has dramatically opened the possibility of producing a variety 
of molecules of nutritional, therapeutic, and industrial importance in plants. Plants as bioreactors have therefore become a major choice for producing recombinant proteins for number of reasons including low cost of production with no safety and environmental issues. The first chimeric gene of human growth hormone is expressed in sunflower and tobacco plants through Ti plasmid [1]. Afterwards, mouse monoclonal antibody (mAb) was functionally produced in tobacco leaf [2]. When plants used as a bioreactor, then they may yield high amounts of recombinant proteins without any contamination of animals or humans pathogens and can be stored for a long duration without refrigeration. A number of recombinant proteins are tried to be produced in plants, and especially proteinbased pharmaceuticals productions have been partially shifted from other expression systems to plants and plant cell cultures [3, 4] (Figs. 1, 2, and 3).

\section{Protein Expression Systems}

\section{Stable Transformation}

Transgenic plants are used as bioreactors for the commercial production of biopharmaceutical because first, to attain high expression level of heterologous recombinant genes; secondly, their maneuver ability for easily design and produce new antigens in response to new pathogen subtypes; and third, to ensure the safety of produced proteins for use in humans or animals.

Fig. 1 Plant expression platforms for the recombinant therapeutic protein production

\section{Nuclear Transformation}

Many crops are nowadays used to transform and raising the transgenics, but the response of regeneration protocols is dependent on recalcitrant nature of specific genotype of the crops which further widened the scope of improvement in existing protocols as well as future protocol development and production of transgenic plants. Although the insertion of DNA can modify both nuclear as well as other organelle genomes, Agrobacterium-mediated transformation can able to produce a stable nuclear transformant. The transformed single host cell can regenerate into a whole plant directly or into a zygotic embryo. Either the haploid plant cells like pollen and egg can directly transform for successfully raising homozygous transgenic line [5] or by transforming non-gametic cells (somatic cells) for generating $\mathrm{T}_{0}$ hemizygous lines which can self-cross to get homozygous lines in subsequent generations [6]. Thus, the establishment of an efficient, stable plant transformation and regeneration protocol is the first step for the continuous production of recombinant biopharmaceutical protein in any crop plant.

\section{Plastid Transformation}

Plant transgenic technologies were restricted to the nuclear genome for many years; however, the expression of human proteins in such cases has been disappointingly low in the range of $0.1-0.002 \%$ of total soluble protein e.g., human serum albumin [7]. The chloroplast is the second genome of the plant cell which can accommodate the genetic engineering changes and accumulates recombinant proteins up to $46 \%$ of

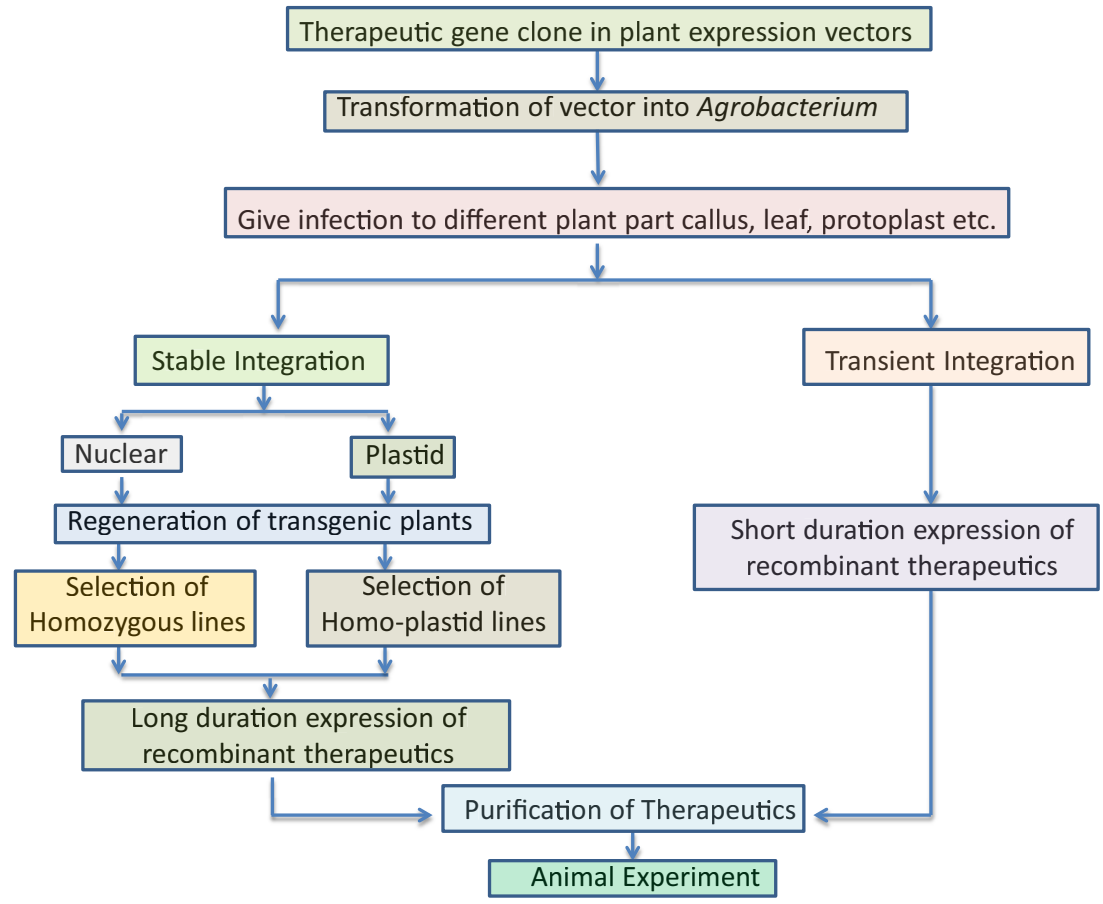


Fig. 2 Comparative statement of different expression systems for recombinant therapeutic production

\begin{tabular}{|c|c|c|c|c|c|}
\hline Traits/Organisms & Bacteria & Yeast & $\begin{array}{l}\text { Mammalian } \\
\text { culture }\end{array}$ & $\begin{array}{c}\text { Transgenic } \\
\text { Animals }\end{array}$ & Transgenic Plants \\
\hline $\begin{array}{l}\text { Required storage } \\
\text { condition }\end{array}$ & Aseptic Cold & Aseptic Cold & Aseptic Cold & Aseptic Cold & $\begin{array}{c}\text { Room } \\
\text { Temperature }\end{array}$ \\
\hline $\begin{array}{l}\text { Cost of } \\
\text { production }\end{array}$ & Medium & Medium & High & High & Low \\
\hline $\begin{array}{c}\text { Glycosylation } \\
\text { Ability }\end{array}$ & No & Medium & High & High & High \\
\hline $\begin{array}{l}\text { Folding accuracy } \\
\text { of produced } \\
\text { therapeutics }\end{array}$ & Low & Medium & High & High & High \\
\hline $\begin{array}{l}\text { Assembly of } \\
\text { multimeric } \\
\text { protein }\end{array}$ & Low & Medium & Medium & High & High \\
\hline $\begin{array}{c}\text { Ease of } \\
\text { Circulation }\end{array}$ & Medium & Medium & Low & Low & High \\
\hline $\begin{array}{l}\text { Scale up } \\
\text { feasibility }\end{array}$ & Low & Low & Medium & Medium & High \\
\hline Safety of system & Low & Low & Low & Medium & High \\
\hline Required Time & Low & Medium & High & High & Medium \\
\hline $\begin{array}{l}\text { Accomodation of } \\
\text { gene size for } \\
\text { expression }\end{array}$ & Low & Medium & Medium & Medium & High \\
\hline Yield & Low & Medium & Medium & High & High \\
\hline & Bacteria & Yeast & Mammalian cells & Transgenic Animal & Transgenic plant \\
\hline
\end{tabular}

the total soluble proteins [8•]. Biolistic and PEG-mediated transformation protocols are two major and important chloroplast transformation methods available [9]. However, it possesses a smaller circular genome of about $290 \mathrm{~Kb}$ with 100 250 genes than nuclear genomes, but plastid contains multiple copies of its genome and presents 50-60 plastids per single leaf cell [10]. The cloned transgene propagates in throughout the pool of plastid genomes which can accumulate large quantities recombinant protein up to $70 \%$ of the total soluble proteins [11•]. A homogenous trans-plastomic line can contain thousands of transgene integration in a single cell. Generation of fertile trans-plastomic lines are reported in potato and tobacco $[12,13]$. However, leafy plants like carrot, petunia, and lettuce have been successfully used for plastid transformation [14, $15 \cdot \bullet]$, but chloroplast is not always the appropriate choice for expression of all the type of protein like glycoproteins and synthetic proteins which may not express correctly and sufficiently [16]. Chloroplast transformation is advantageous for not only yield of desired proteins like somatotropin (7\%), CTB (4.1\%), and Bt toxin (5\%) [17••, 18, 19], but also its maternally stable expression which restricts transgene dispersal as per the GMO compliance.
Fig. 3 Commercial production and assessment of recombinant therapeutics

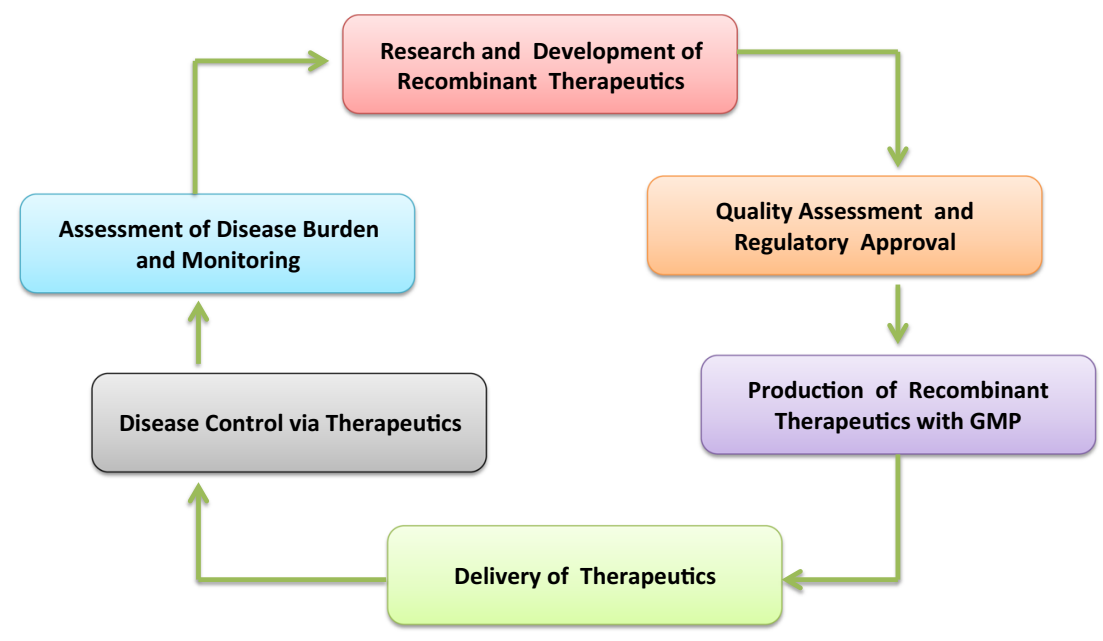




\section{Transient Transformation}

Transient expression of genes can provide advantages like the rapid production of protein, lack position effect, and ability to use recalcitrant plant genotypes for production. Many plant viruses like tobacco mosaic virus (TMV), cowpea mosaic virus (CPMV), alfalfa mosaic virus, potato virus (PVX) have been used successfully for this purpose [20]. However, initially first generation plant-based vaccines were produced against influenza virus [21, 22], human papilloma virus [23, 24], and norovirus [25] by modifying PVX or TMV. Nowadays, second-generation deconstructed viral vector that devoid of different viral elements which important for vector replication, DNA delivery, and their infectivity. These vectors are environmentally safe and usually provide high yield [20, 26]. But recombinant viruses which contain heterologous coat protein and sub-genomic promoters appeared much more stable [27]. Though in this system, only $5 \%$ of the coat protein was produced recombinantly [28-30]. It was also advantageous for cell surface presentation of foreign antigen along with viral coat protein. AMV coat proteins can accommodate more than 25 amino acid peptide as compare to TMV. This ability can also be utilized for the production of different subunit recombinant vaccines [28, 31, 32]. However, the stability of foreign gene containing viruses varies but loss of inserted genes was observed in each case [27]. To evaluate the transient expression of a tumor-specific antibody in tobacco vacuum infiltration of Agrobacterium were performed by Vaquero et al., [33]. The full-sized assembled antibody was accumulated to $1 \mathrm{mg} / \mathrm{kg}$ in fresh tobacco leaf by the infiltration of two independent Agrobacterium strains.

\section{Recombinant Therapeutics for Humans}

\section{Vaccines}

\section{Hepatitis $B(H B V)$}

Plant-based vaccination strategy for HBV has been explored by a number of research groups. A modified N-terminus version of HBsAg was designed to present for both $\mathrm{T}$ cell and $\mathrm{B}$ cell epitopes. Modification of the antigen did not negatively impact its ability to form virus-like particles, indicating that this modified version of the antigen can be used to elicit a multivalent response [34]. The rice seed promoter Glub-4 was also utilized for cloning and expression of HBV antigen in rice seed. Binding region of pre-S1 (21-47 amino acid presurface-1) hepatocyte receptor was C-terminally linked with surface antigen (S) of HBV to form SS1 gene [35]. Antibodies that can be elicited from this pre-S1 region could then block against HBV binding to hepatocytes. This HBV fusion product was expressed at levels as great as $31.5 \mathrm{ng} \mathrm{g}-{ }^{1}$ of dry rice seed weight. Immunization of $\mathrm{BALB} / \mathrm{c}$ mice with purified SS1 protein was able to induce antibodies against both pre$\mathrm{S} 1$ and S antigens. Youm et al. [36] used a variety of orally administered doses of potato-derived HBsAg to determine their effects on the mouse immune response. In another study, transgenic tomato plants have also been used as an expression platform for HBsAg. Lou et al. [37] used different construct designs to optimize levels of HBV antigen for higher and more stable accumulation of HBsAg in tomato. HBsAg has also been expressed in lettuce, through the generation of transgenic plants via co-cultivation of cotyledons with Agrobacterium harboring the gene of interest [38].

\section{HIV (Human Immunodeficiency Virus)}

Nef Gene Nef protein is involved in HIV progression and expressed in early stages of viral life cycle. Mutations in the nef gene are associated with long-term non-progression of virus in patients [39]. It can be found in the cells as two main isoforms translated by two in-frame translational start codons, p27 $(27 \mathrm{kDa})$, which represent the full-length viral protein and p25 (25 kDa), 18 amino acid truncated form. N-terminal addition of myristoyl group is necessary for Nef protein anchoring at the cytosolic side of the membrane [40]. Use of a recombinant non-myristoylated Nef is considered advantageous in the production of a multicomponent vaccine as myristoylation site deletion abrogates Nef-mediated suppression of MHCI and CD4 cell-surface molecules [41, 42], which typically prevent the lysis of HIV-1-infected primary cells through cytotoxic T lymphocyte [43]. Overall data indicate that plant-produced Nef could be effective in a prime-boost vaccination strategy.

Tat Gene HIV-1 Tat regulatory protein is a small nuclear molecule and enhances the efficiency and initiation of viral transcription. Tat is a well-conserved protein, particularly within its N-terminal residues [44]. Like Nef, Tat has also been expressed in plants as full-length or as a fusion protein in the attempt to improve its accumulation or immunogenicity. In 2007, the expression of HIV-1 Tat in tomato fruit and its immunogenicity was reported. Tat was also expressed in tomato plants fused to GUS protein (E-glucuronidase). Plant extracts were used to inject mice intradermally, and both Tat-specific antibody response and cytotoxic T lymphocyte (CTL) activity were shown [45]. The immunologically potential plant-produced HIV-1 p24 was obtained when p24 and IgA genes were engineered to express an antigen-antibody fusion protein in the ER of transgenic tobacco cells. Two recombinant proteins were detected, a monomer of $58 \mathrm{kDa}$ and a dimer of $110 \mathrm{kDa}$, both recognized by $\mathrm{p} 24$-specific antibodies, indicating that the antigen was properly folded [46]. 


\section{Chimeric HIV Envelope Proteins}

Viral pathogens like HIV-1 have developed the strategy to mutate surface proteins to escape recognition by immune cells rapidly. However, viral envelope proteins still harbor highly conserved peptides that are often associated with the production of neutralizing antibodies and known as "protective epitopes." Even though cellular immunity may provide control of HIV replication, neutralizing antibodies represent the first protective barrier useful to reduce the viral load during the early stage of infection. As small molecules like peptides have low immunogenic potential, one strategy to produce subunit vaccines consists of the fusion of protective epitopes to heterologous carrier proteins (CPs). As a carrier of immunogenic peptides, plant viruses were successfully used to prepare chimeric viral particle (CVPs). CVPs demonstrated their efficiency in neutralizing anti-HIV immune responses. However, virus-like particles (VLPs) which do not contain the viral genome and are not infectious represent ideal particles regarding biosafety for the generation of novel plant virus-derived vaccine components.

\section{Rabies}

The rabies glycoprotein is the major antigen in the rabies coat protein. Agrobacterium-mediated transformation and expression of rabies antigen were first reported in tomato [47]. The glycoprotein expresses up to $10 \mathrm{ng} / \mathrm{mg}$ in the leaves with a differential glycosylated protein band of 60 and $62 \mathrm{kDa}$. In another report, mice were vaccinated with transformed tobacco and spinach leaves via oral and intraperitoneal routes [48]. Only $40 \%$ animals were survived during the viral challenge. Edible rabies vaccines were also tried to develop in maize and carrots. When challenged with vampires originated virus, it provides $100 \%$ protection in mice $[49,50 \bullet$. Biolistic transformation of maize embryogenic callus was done with the construct containing expression cassette of rabies $G$ gene and CaMV35S promoters which flanked with matrix attachment regions (MARs). During oral administration of pellet formed with fine corn powder, all the animals were survived in the intra-cerebral viral challenge. Ashraf et al. fused full-length rabies glycoprotein gene with endoplasmic reticulum retention sequence (SEKDEL) and optimized the gene with plantspecific codons to improve its expression in plant [51・•]. The expression of $\sim 66 \mathrm{kDa}$ rabies glycoprotein in tobacco was $0.38 \%$ of the leaves TSP. Intraperitoneal immunization of the mice was done through $25 \mu \mathrm{g}$ of rabies glycoprotein, and later mice were intra cerebrally challenged with CVS strain of rabies. Plant-derived $\mathrm{G}$ protein provides complete protection to the mice as a commercial vaccine. Furthermore, Ricin toxin B subunit (RTB) and Cholera toxin B chain (CTB) were used to explore their ability as both $\mathrm{C}$-terminal and $\mathrm{N}$ - terminal fusion partner for Rabies glycoprotein (RGP) and utilized them as a recombinant mucosal carrier which has binding ability to the receptors of the epithelial membrane $[52,53 \bullet \cdot, 54]$. Recombinant chimeric gene rgp-rtxB which formed by the fusion of rabies G-protein (rgp) and ricin toxin B chain (RTB) antigenic genes were cloned in the downstream of CaMV35S double enhancer-promoter and used to express in hairy roots of $S$. lycopersicum. Recombinant fusion protein expressed up to $8 \mu \mathrm{g} / \mathrm{g}$ of tomato hairy roots [55•].

\section{Plantibodies for Humans}

Hybridoma-derived y and $\mathrm{k}$ chains of murine antibody was first individually expressed in a plant in low concentration, but when these transgenic lines crossed with each other, the expression of assembled and functional antibody reaches up to $1.3 \%$ of leaf protein [2]. A flexible peptide chain linked variable domain of light and heavy chain of a synthetic antibody which called single-chain fragment variable $(\mathrm{scFv})$. Two scFvs of different specificity can link with Trichoderma's cellobiohydrolase I linker to achieve unique bispecific therapeutic scFvs [56].

\section{Tumor Epitope Antibodies}

Light and heavy chains of monoclonal antibody for colon cancer antigen (CO17-1A) were independently engineered into TMV vector and co-infect the tobacco to produce assembled full-length plant antibody [57]. Similar attempts were also made to express an assembled antibody of human carcinoembryonic antigen into tobacco. Vaquero et al. (1999) utilized two different Agrobacterium strains for simultaneous transient production and assembly of light and heavy chain in tobacco [33]. Single-chain Fv fragment for tumor epitope was also transiently expressed in tobacco through tobamoviral vector which induces protective murine immune response [58]. Advantages over traditional methods based on mammalian cells are the adaptability and speed of these novel plant expression systems and also the reduced costs [59].

\section{Herbicides Antibodies}

Herbicides are major organic pollutant which contaminates water and soil of agricultural areas. There is always a possibility of residual contamination in agricultural and processed food product which imparts adverse impact on human health. So, antibody-based immuno-detection of this residual contaminant is useful. Paraquat and atrazine herbicide-specific scFvs were expressed at $0.014 \%$ of TSP in tobacco leaves [60]. Similarly, diuron-specific $\mathrm{scFv}$ were transiently produced in the range of $0.1-0.25 \%$ of TSP through PVX system [61]. 


\section{Streptococcus Mutans' Antibodies}

Streptococcal cell surface adhesion antigen is a major reactive immunogenic molecule which known as Guy's 13. Correctly assembled recombinant Guy's 13 monoclonal antibodies were produced in tobacco [62]. Later secretory version of immunoglobulin $\mathrm{A}$ and $\mathrm{G}$ were also produced. However, analysis of $\mathrm{N}$-linked glycosylation of IgG shows different glycosylation composition in which $60 \%$ contains $(1,2)$ xylose and $(1,3)$ fucose glycan residues [63] which might induce an immunogenic response. But the glycan or protein-specific antibodies against plant produced Guy's 13 were not observed during murine immunogenicity experiment [64]. Similarly, application of these antibodies was failed to prevent dental carries in humane caused due to Streptococcus mutans [65••]. The partially galactosylated murine antibody was produced in the plant when it crossed with another human 1, 4 galactosyltransferases transgene expressing plant [66]. This strategy can provide the solution for conflict due to the absence of transgene-related glycosylation pattern.

\section{Supplements and Effector Molecules for Humans}

Cytokines participate in various physiological processes like cell cycle and cell signaling and can be used for therapeutic purpose. IL-2, IL-11, GM-CSF, erythropoietin, and interferons like cytokines have established the clinical applications $[67,68]$. Agrobacterium-mediated transformation and expression of various cytokines were done in tobacco. However, expression and accumulation of these genes were lower than the expectation. But, the biological activity of these recombinant cytokines was at par in in vitro assays. The shorter halflife of these cytokines could be the reason of lower expression. Interestingly, the expression of hIL-10 (humane interleukin10) cytokines was increased up to 70 fold $(55 \mathrm{ng} / \mathrm{mg}$ protein) in ER lumen and its productio in low nicotin tobacco cultivar (cv. 81V9) make the oral administration of plant crude extract possible at a lower concentration.

\section{Recombinant Immunotherapeutic for Animals}

\section{Virus-like Particle (VLP) for Animals}

The most important cause of severe losses in livestock production worldwide is viral disease. Vaccinations can not only control viral infections but also help to reduce the use of antibiotics during secondary infection in livestock. As we have seen earlier in the case humane, virus-like particles (VLPs) are used as multi-subunit protein vaccines which have the selfassembling capability and identical to the overall structure of native viruses [69]. Due to display ability of multimeric antigens to the immune system, VLPs can induce both humoral as well as cell-mediated immune response in greater degrees than normal monomeric subunit vaccines. VLPs do not need any adjuvants which also stimulate inflammatory $\mathrm{T}$ cell response [70]. VLPs derived from phages, insect, plant, and vertebrate viruses and can produce in large quantities in bacteria, yeast, mammalian, and insect cell lines [69]. The first report of plantbased expression of human hepatitis B virus antigen containing VLPs came in 1992 [71]. Further production of HIV-1 and HBV bivalent antigens through VLPs nanoparticles demonstrates the ability of this technology [72•]. Transient expression of Bluetongue virus (BTV) antigens as hetero-multimeric VLPs was able to induce a strong antibody response in sheep against BTV virus challenge [73]. Improved transient expression of Norwalk virus-derived VLPs in-plant is also shown [74]. Methods of Norwalk virus capsid protein expression in lettuce leaves and their scalability was also demonstrated by Lai et al. [75]. To avoid immune tolerance via insufficient antigen application through the oral route, VLP vaccine must be enriched, processed, and formulated as per standard practice [69]. Medicago Inc. has successfully used VLP-based plant transient expression system to produce influenza hemagglutinin vaccines (H1N1) [76]. The biggest achievement of this developed platform is that it gives the ability to develop any vaccine in a short span after knowing the antigen sequence and reduces down processing cost to ensure the low economic burden of veterinary vaccines [77].

\section{Subunit Vaccines}

In the past decades, there were many attempts to develop the veterinary subunit vaccine to counter various diseases, but only a few were conducted in animals; these are summarized below as per animal specificity.

\section{Poultry}

In poultry, three major viral diseases are infectious bronchitis (IBV), infectious bursal disease (IBDV), and Newcastle disease (NDV). Infectious bronchitis virus (IBV) S1 glycoprotein was expressed in potato, and in another study VP2 protein of infectious bursal disease virus (IBDV) was expressed in rice seeds, were used to immunize the chicken orally and was found equally protective as a commercial vaccine [78]. However, transiently expressed VP2 antigen in Nicotiana benthamiana also induced neutralizing antibodies in chickens [79]. Expression of the recombinant hemagglutininneuraminidase coat protein of Newcastle disease virus in tobacco suspension culture and their injectable vaccine got USFDA approval in 2006 [80]. Expression of full-sized glycoprotein in rice and maize seed were subjected to efficacy test in other experiments [81]. 
Swine

Swine are also infected with gut-related infectious bacteria and viruses. Bacterial entero-toxin produced by $E$. coli (ETEC) causes diarrhea in piglets. Along with this, frequent porcine gastro-enteritis disease is caused by a virus known as transmissible gastroenteritis coronavirus (TGEV). Subunit protein F4 fimbriae of ETEC are expressed in both seeds of barley [82] and leaves of tobacco [83] and alfalfa [84]. However, it is immunogenic but gives partial protection to piglets on oral delivery [84]. Whereas, envelope spike protein of TGEV expressed in maize seed shown their efficacy by producing neutralizing antibodies in piglets [85]. In addition to this, their one study in which coat protein of Bamboo mosaic virus was replaced with VP1 antigenic capsid protein of foot-and-mouth disease virus (FMDV) results into chimeric virion which retains their infectivity for propagation and expression of this VP1 antigenic in plants. Extracted chimeric virion was shown complete protection on intramuscular immunization of pigs [86].

\section{Cattle}

Hemagglutinin of bovine rinderpest virus expressed in peanut which induces the virus neutralizing antibody when orally vaccinated the cattle [87]. Glycoprotein D of bovine herpes virus (BHV) was expressed in tobacco as tobacco mosaic virus-based vaccine which in turn was able to induce humoral and cellular immunity against BHV when injected into the castles [88]. In Argentina, a fusion product of E2 subunit of bovine viral diarrhea virus (BVDV) structural protein with peptide for targeting antigen presenting cell was expressed in alfalfa. This plant-made subunit vaccine partially purified and gave protection to calves on intramuscular administration [89]. Rabies virus is a zoonotic disease which transmitted from bats, raccoons, and foxes types of wild animals to pet animals and cattle. However, large numbers of wild animals pose a major hurdle for injectable vaccination, but bait mixed low-cost oral vaccine distribution in the endemic regions could provide a major solution for rabies control [90]. Hence, plant-based rabies virus glycoprotein (RVG) has been expressed in several plant species like tobacco, tomato, spinach, carrot, groundnut, and maize [47, 50•, 52, 55•, 91, 92]. Maize-produced rabies glycoprotein was used to immunize the sheep and also able to protect the animal during a viral challenge in a dose-dependent manner [93•]. This report suggests that plant-made rabies subunit may use as vaccine antigen in a different animal with variable potency.

\section{Plantibodies for Animals}

The first plant expressed IgG antibody was shown in 25 years back. Since then, various scientific reports have shown the ability of plant-produced antibodies against various pathogens diseases like cancer, HIV, and Ebola. [94]. Ebola epidemic that caused in West Africa draw the attention over plantproduced antibody cocktail ZMAPP. It protects the all the Rhesus macaques even at the advanced stage of Ebola disease [95]. Sporozoite-neutralizing single-chain antibodies against Coccidiosis parasite and Eimeria tenella were produced in pea and successfully prevent the gastrointestinal infections in chickens [96]. In another study, protection against enterotoxigenic E.coli infection in weaned piglets was achieved by oral administration of seeds IgA [97]. Though, single -chain antibody easily expressed in bacteria but for the production of complex glycoprotein, monoclonal antibody requires costeffective eukaryotic production system. The presence of molecular chaperone and glycosylation system, all the four glycosylated polypeptide expresses well in the in-plant expression system. Plants can easily produce secretory antibody IgA because they cannot only express but also assemble all four polypeptide components into a fully functional molecule [98]. Hence, plants can provide a valuable and superior large-scale protein expression system for mucosal antibodies.

\section{Supplements and Effector Molecules for Animals}

Due to the antibiotic resistance, the efficiency of the antibiotic gets declined against the major pathogenic bacteria sharply which limits our alternative to fight the infections. One of the prudent therapeutic options is lysin enzymes which hydrolyze the cell wall of bacteria and effectively check the populations of bacteria [99]. Plants can provide a cost-effective alternative platform for the production of any toxic bacterial proteins. Hence, expression and accumulation of functional lysozyme $\mathrm{Cpl}-1$ and the amidase $\mathrm{Pal}$ genes were shown in tobacco plastid [100]. A short anti-microbial peptide which analogs of defensins and controls the viral, bacterial, and fungal infections were expressed in both transiently and transplastomic lines [101-103]. In the purview of the above, we can conclude that plants may offer cost-effective protein expression platform to express vaccine, anti-microbial peptides, antibodies, supplements, and antibiotics which can administer to animals in anyways through orally, intravenous, and intramuscular depending upon our need.

\section{Conclusion}

Plants as bioreactors provide a valuable platform for the production of recombinant therapeutic proteins for human as well as animal health. In recent years, successful commercialization of plant-produced antibodies and supplements provides the opportunity to explore this area more rigorously through biotechnological intervention for the solution of inherent problems of this system like plant-specific glycosylation and 
long-term expression stability. However, numerous studies demonstrated the advantages and feasibility of low-cost plant-based production platforms for various therapeutic proteins range from complex antibodies, therapeutic supplements, subunit vaccines, and immunogenic virus-like particles, but due to strict GMO regulation, very few therapeutic proteins can successfully pass this compliance and commercialize. Hence, we should more focus toward compliance fitted antibodies, VLP-based multivalent subunit vaccines, and therapeutic and food supplements especially for animals and then for human step-by-step manner to maintain our momentum.

\section{Compliance with Ethical Standards}

Conflict of Interest Ankit Singh, Gurminder Kaur, Neetu Singh, Sanchita Singh and Gauri Saxena declare that they have no conflicts of interest.

Human and Animal Rights and Informed Consent This article does not contain any studies with human or animal subjects performed by any of the authors.

\section{References}

Papers of particular interest, published recently, have been highlighted as:

- Of importance

•. Of major importance

1. Barta A, Sommergruber K, Thompson D, Hartmuth K, Matzke M, Matzke A. The expression of a nopaline synthase-human growth hormone chimeric gene in transformed tobacco and sunflower callus tissue. Plant Mol Biol. 1986;6(5):347-57. https://doi.org/ 10.1007/BF00034942.

2. Hiatt A, Cafferkey R, Bowdish K. Production of antibodies in transgenic plants. Nature. 1989;342:76-8. https://doi.org/10. 1038/342076a0.

3. Lico C, Santi L, Twyman R, Pezzotti M, Avesani Tywa L. The use of plants for the production of therapeutic human peptides. Plant Cell Rep. 2012;31:439-51. https://doi.org/10.1007/s00299-0111215-7.

4. Merlin M, Gecchele E, Capaldi S, Pezzotti M, Avesani L. Comparative evaluation of recombinant protein production in different biofactories: the green perspective. Biomed Res Int. 2014;2014:1-14. https://doi.org/10.1155/2014/136419.

5. Ye G-N, Stone D, Pang S-Z, Creely W, Gonzalez K, Hinchee M. Arabidopsis ovule is the target for agrobacterium in planta vacuum infiltration transformation. Plant J. 1999;19:249-57.

6. Horsch RB, Fry JE, Hoffman NL, Eichholtz D, Rogers SG, Faley RT. A simple and general method of transferring genes into plants. Science. 1985;227:1229-31. https://doi.org/10.1126/science.227. 4691.1229.

7. Kusnadi AR, Nikolov ZL, Howard JA. Production of recombinant proteins in transgenic plants: practical considerations. Biotechnol Bioeng. 1997;56(5):473-84. https://doi.org/10.1002/(SICI)10970290(19971205)56:5<473::AID-BIT1>3.0.CO;2-F.
8. De Cosa B, Moar W, Lee SB, Miller M, Daniell H. Overexpression of the Bt cry2Aa2 operon in chloroplasts leads to formation of insecticidal crystals. Nat Biotechnol. 2001;19:714. https://doi.org/10.1038/83559. This study demonstrated introduction of several genes into the chromoplast genome and confirmed their stable integration in $T_{0}$ and $T_{1}$ transgenic plants.

9. Cardi T, Lenzi P, Maliga P. Chloroplasts as expression platforms for plant produced vaccines. Expert Rev. 2010;9:893-911. https:// doi.org/10.1586/erv.10.78.

10. Bogorad L. Engineering chloroplasts: an alternative site for foreign genes, proteins, reactions and products. Trends Biotechnol. 2000;18:257-63.

11. Oey M, Lohse M, Scharff LB, Kreikemeyer B, Bock R. Plastid production of protein antibiotics against pneumonia via a new strategy for high-level expression of antimicrobial proteins. Proc Natl Acad Sci U S A. 2009;106:6579-84. https://doi.org/10.1073/ pnas.0813146106. This work demonstrated the applicability of the strategy by the high-level expression in plastids (to up to $30 \%$ of the plant's total soluble protein) of 2 phage-derived protein antibiotics that are toxic to $E$. coli.

12. Svab Z, Hajdukiewicz P, Maliga P. Stable transformation of plastids in higher plants. Proc Natl Acad Sci U S A. 1990;87:8526-30.

13. Sidorov VA, Kasten D, Pang SZ, Hajdukiewicz PT, Staub JM, Nehra NS. Stable chloroplast transformation in potato: use of green fluorescent protein as a plastid marker. Plant J. 1999;19: 209-16.

14. Rigano M, Walsley A. Expression systems and developments in plant-made vaccines. Immunol Cell Biol. 2005;83:271-7. https:// doi.org/10.1111/j.1440-1711.2005.01336.x.

15.• Verma D, Daniell H. Chloroplast vector systems for biotechnology applications. Plant Physiol. 2007;145:1129-43. https://doi.org/ 10.1104/pp.107.106690. This article reports the utility of chloroplast vector system for enhanced protein yield.

16. Guda C, Lee SB, Daniell H. Stable expression of a biodegradable protein-based polymer in tobacco chloroplasts. Plant Cell Rep. 1999;19:257-62.

17.• Staub IM, Garcia B, Graves J, Hajdukiewicz PT, Hunter P, Nehra $\mathrm{N}$, et al. High-yield production of a human therapeutic protein in tobacco chloroplasts. Nat Biotechnol. 2000;18:333-8. https://doi. org/10.1038/73796. This article report for the use of chloroplast expression system for the high yield of therapeutic protein in plants.

18. Daniell H, Muthukumar B, Lee S. Marker free transgenic plants: engineering the chloroplast genome without the use of antibiotic selection. Curr Genet. 2001;39:109.

19. McBride KE, Schaaf DJ, Daley M, Stalker DM. Controlled expression of plastid transgenes in plants based on a nuclear-encoded and plastid targeted T7 RNA polymerase. Proc Natl Acad Sci U S A. 1994;91:7301-5.

20. Salazar-González J, Bañuelos-Hernández B, Rosales-Mendoza S. Current status of viral expression systems in plants and perspectives for oral vaccines development. Plant Mol Biol. 2015;87: 203-17. https://doi.org/10.1007/s11103-014-0279-5.

21. Ravin N, Kotlyarov R, Mardanova E, Kuprianov V, Migunov A, Stepanova LA, et al. Plant produced recombinant influenza vaccine based on virus-like HBc particles carrying an extracellular domain of M2 protein. Biochemist. 2012;77:33-40.

22. Shoji Y, Chichester J, Jones M, Manceva S, Damon E, Mett V, et al. Plant-based rapid production of recombinant subunit hemagglutinin vaccines targeting $\mathrm{H} 1 \mathrm{~N} 1$ and $\mathrm{H} 5 \mathrm{~N} 1$ influenza. Hum Vaccin. 2011;7:41-50.

23. Cerovska N, Hoffmeisterova H, Moravec T, Plchova H, Folwarczna J, Synkova H, et al. Transient expression of human papillomavirus type $16 \mathrm{~L} 2$ epitope fused to $\mathrm{N}$ - and $\mathrm{C}$-terminus of coat protein of potato virus X in plants. J Biosci. 2012;37:125-33. 
24. Noris E, Poli A, Cojoca R, Rittà M, Cavallo F, Vaglio S, et al. A human papillomavirus $8 \mathrm{E} 7$ protein produced in plants is able to trigger the mouse immune system and delay the development of skin lesions. Arch Virol. 2011;156:587-95. https://doi.org/10. 1007/s00705-010-0893-8.

25. Lai H, Chen Q. Bioprocessing of plantderived virus-like particles of Norwalk virus capsid protein under current good manufacture practice regulations. Plant Cell Rep. 2012;31:573-84. https://doi. org/10.1007/s00299-011-1196-6.

26. Peyret $\mathrm{H}$, Lomonossoff $\mathrm{G}$. The $\mathrm{pEAQ}$ vector series: the easy and quick way to produce recombinant proteins in plants. Plant Mol Biol. 2013;83:51-8. https://doi.org/10.1007/s11103-013-0036-1.

27. Yusibov VA, Shivprasad S, Turpen RH, Dawson W, Koprowski H. Plant viral vectors based on tobamoviruses. Curr Top Microbiol Immunol. 1999;240:81-94.

28. Turpen TH, Reinl SI, Charoenvit Y, Hoffman SL, Fallarme V, Grill LK. Malarial epitopes expressed on the surface of recombinant tobacco mosaic virus. Biotechnology (NY). 1995;13:53-7.

29. Hamamoto H, Sugiyama Y, Nakagawa N, Hashida E, Matsunaga $\mathrm{Y}$, Takemoto S, et al. A new tobacco mosaic virus vector and its use for the systemic production of angiotensin -I-converting enzyme inhibitor in transgenic tobacco and tomato. Biotechnology (N Y). 1993;2:930-2.

30. Skuzeski JM, Nichols LM, Gesteland RF, Atkins JF. The signal for a leaky UAF stop codon in several plant viruses includes that two downstream codons. J Mol Biol. 1991;218(2):365-73.

31. Yusibov VA, Modelska K, Steplewski M, Agadjanyan M, Weiner D, Hooper DC, et al. Antigens produced in plants by infection with chimeric plant viruses immunize against rabies virus and HIV-1. Proc Natl Acad Sci U S A. 1997;94:5784-8.

32. Belanger H, Fleysh N, Cox S, Bartman G, Deka D, Trudel M, et al. Human respiratory syncytial virus vaccine antigen produced in plants. FASEB J. 2000;14:2323-8. https://doi.org/10.1096/fj.000144com.

33. Vaquero C, Sack M, Chandler J, Drossard J, Schuster F, Monecke $\mathrm{M}$, et al. Transient expression of a tumor-specific single-chain fragment and a chimeric antibody in tobacco leaves. Proc Natl Acad Sci U S A. 1999;96:11128-33.

34. Richter LJ, Thanavala Y, Arntzen CJ, Mason HS. Production of hepatitis surface antigen in transgenic plants for oral immunization. Nat Biotechnol. 2000;18:1167-71. https://doi.org/10.1038/ 81153.

35. Qian B, Shen H, Liang W, Guo X, Zhang C, Wang Y, et al. Immuno-genicity of recombinant hepatitis B virus surface antigen fused with preS1 epitopes expressed in rice seeds. Trans Res. 2008;17(4):621-31. https://doi.org/10.1007/s11248-007-9135-6.

36. Youm JW, Won YS, Jeon JH, Moon KB, Kim HC, Shin KS, et al. Antibody responses in mice stimulated by various doses of the potato-derived major surface antigen of hepatitis B virus. Clinical Vaccine Immunol. 2010;17(12):2029-32.

37. Lou XM, Yao QH, Zhang Z, Peng RH, Xiong AS, Wang HK. Expression of the human hepatitis B virus large surface antigen gene in transgenic tomato plants. Clinical and Vaccine Immunol. 2007;14(4):464-9. https://doi.org/10.1128/CVI.00321-06.

38. Marcondes J, Hansen E. Transgenic lettuce seedlings carrying hepatitis B virus antigen HBsAg. Brazilian J of Infectious Disease. 2008;12(6):469-71.

39. Cruz NV, Amorim R, Oliveira FE, Speranza FA, Costa LJ. Mutations in the nef and vif genes associated with progression to AIDS in elite controller and slow-progressor patients. J Med Virol. 2013;85(4):563-74. https://doi.org/10.1002/jmv.23512.

40. Geyer M, Fackler OT, Peterlin BM. Structure-function relationships in HIV-1 Nef. EMBO Rep. 2010;2:580-5. https://doi.org/10. 1093/embo-reports/kve141.
41. Peng B, Robert-Guroff M. Deletion of N-terminal myristoylation site of HIV Nef abrogates both MHC-1 and CD4 down-regulation. Immunol Lett. 2001;78:195-200.

42. Peng B, Voltan R, Cristillo AD, Alvord WG, Davis-Warren A, Zhou Q, et al. Replicating Ad-recombinants encoding nonmyristoylated rather than wild-type HIV Nef elicit enhanced cellular immunity. AIDS. 2006;20:2149-57. https://doi.org/10.1097/ QAD.0b013e32801086ee.

43. Collins KL, Chen BK, Kalams SA, Walker BD, Baltimore D. HIV-1 Nef protein protects infected primary cells against killing by cytotoxic T lymphocytes. Nature. 1998;391:397-401. https:// doi.org/10.1038/34929.

44. Debaisieux S, Rayne F, Yezid H, Beaumelle B. The ins and outs of HIV-1 Tat. Traffic. 2012;13:355-63. https://doi.org/10.1111/j. 1600-0854.2011.01286.x.

45. Cueno ME, Hibi Y, Karamatsu K, Yasutomi Y, Imai K, Laurena AC, et al. Preferential expression and immunogenicity of HIV-1 Tat fusion protein expressed in tomato plant. Trans Res. 2010;19: 889-95. https://doi.org/10.1007/s11248-009-9358-9.

46. Obregon P, Chargelegue D, Drake PM, Prada A, Nuttall J, Frigerio L, et al. HIV-1 p24-immunoglobulin fusion molecule: a new strategy for plant-based protein production. Plant Biotechnol J. 2006;4:195-207. https://doi.org/10.1111/j.1467-7652.2005. 00171.x.

47. McGarvey PB, Hammond J, Dienelt MM, Hooper DC, Fu ZF, Dietzschold B, et al. Expression of the rabies virus glycoprotein in transgenic tomatoes. Biotechnol. 1995;13:1484-8.

48. Modelska A, Dietzschold B, Sleysh N, Fu ZF, Steplewski K, Hooper DC, et al. Immunization against rabies with plantderived antigen. Proce of the Natl Acad of Sci USA. 1998;95: 2481-5.

49. Loza-Rubio E, Rojas AE, Gómez NL, Olivera MT, Gómez-Lim MA. Development of an edible rabies vaccine in maize using the Vnukovo strain. Dev Biol. 2008;131:477-82.

50. Rojas-Anaya E, Loza-Rubio E, Flores OMT, Gómez-Lim MA. Expression of rabies virus $\mathrm{G}$ protein in carrots (Daucus carota). Transgenic Res. 2009;18:911-9. https://doi.org/10.1007/s11248009-9278-8. This research paper report the expression of rabies virus $\mathbf{G}$ protein into carrots.

51.• Ashraf S, Singh PK, Yadav DK, Shahnawaz M, Mishra S, Sawant $\mathrm{SV}$, et al. High level expression of surface glycoprotein of rabies virus in tobacco leaves and its immunoprotective activity in mice. J Biotechnol. 2005;119:1-14. https://doi.org/10.1016/j.jbiotec. 2005.06.009. This research paper report for the first time the expression of rabies glycoprotein in tobacco and immunoprotection was demonstrated in mice.

52. Tiwari S, Mishra DK, Roy S, Singh A, Singh PK, Tuli R. High level expression of a functionally active cholera toxin B: rabies glycoprotein fusion protein in tobacco seeds. Plant Cell Rep. 2009;28:1827-36. https://doi.org/10.1007/s00299-009-0782-3.

53.• Roy S, Tyagi A, Tiwari S, Singh A, Singh PK, Sawant SV, et al. Rabies glycoprotein fused with B subunit of cholera toxin is expressed at high level in tobacco plants and folds into biologically active pentameric protein. Protein Exp Purifi. 2010;70:184-90. This research article emphasises the need of correct folding of fusion protein (RGP-CT) to be biologically active.

54. Singh A, Yadav D, Rai KM, Srivastava M, Verma PC, Singh PK, et al. Enhanced expression of rabies virus surface G-protein in Escherichia coli using SUMO fusion. Protein J. 2012;31:68-74. https://doi.org/10.1007/s10930-011-9373-6.

55. Singh A, Srivastava S, Chouksey A, Panwar BS, Verma PC, Roy $\mathrm{S}$, et al. Expression of rabies glycoprotein and ricin toxin $\mathrm{B}$ chain (RGP-RTB) fusion protein in tomato hairy roots: a step towards oral vaccination for rabies. Molecular Biotech. 2015;57:359-70. https://doi.org/10.1007/s12033-014-9829-y. This research paper report the expression of fusion protein (RGP-RTB) in hairy 
root culture of tomato which was further up scaled in bioreactor for large scale cultivation.

56. Fischer R, Schumann O, Zimmermann S, Drossard J, Sack M, Schillberg S. Expression and characterization of bispecific single-chain Fv fragments produced in transgenic plants. Eur J Biochem. 1999;262:810-6.

57. Verch T, Yusibov V, Koprowski H. Expression and assembly of a full-length monoclonal antibody in plants using a plant virus vector. J Immunol Methods. 1998;220:69-75.

58. McCormick AA, Kumagai MH, Hanley K, Turpen TH, Hakim I, Grill LK, et al. Rapid production of specific vaccines for lymphoma by expression of the tumor-derived single-chain Fv epitopes in tobacco plants. Proc Natl Acad Sci U S A. 1999;96(2):703-8.

59. Komarova TV, Baschieri S, Donini, Marusic C, Benvenuto E, Dorokhov YL. Transient expression systems for plant-derived biopharmaceuticals. Expert Rev Vaccines. 2010;9:859-76. https://doi.org/10.1586/erv.10.85.

60. Longstaff M, Newell CA, Boonstra B, Strachan G, Learmonth D, Harris WJ, et al. Expression and characterisation of single-chain antibody fragments produced in transgenic plants against the organic herbicides atrazine and paraquat. Biochem Biophys Acta. 1998;1381:147-60.

61. Smolenska L, Roberts IM, Learmonth D, Porter AJ, Harris WJ, Wilson TM, et al. Production of a functional single chain antibody attached to the surface of a plant virus. FEBS Lett. 1998;441:37982.

62. Ma JK, Lehner T, Stabila P, Fux CI, Hiatt A. Assembly of monoclonal antibodies with IgG1 and IgA heavy chain domains in transgenic tobacco plants. Eur J Immunol. 1994;24:131. https:// doi.org/10.1002/eji.1830240120.

63. Cabanes-Macheteau M, Fitchette-Laine AC, Loutelier-Bourhis C, Lange C, Vine ND, Ma JK, et al. N-Glycosylation of a mouse IgG expressed in transgenic tobacco plants. Glycobiology. 1999;9: 365-72.

64. Chargelegue D, Vine ND, van Dolleweerd CJ, Drake PM, Ma JK. A murine monoclonal antibody produced in transgenic plants with plant-specific glycans is not immunogenic in mice. Transgenic Res. 2000;9(3):187-94.

65.• Ma JK-C, Hikmat BY, Wycoff K, Vine ND, Chargelegue D, Yu L, et al. Characterization of a recombinant plant monoclonal secretory antibody a preventive immunotherapy in humans. Nature Med. 1998;4:601-6. This study demonstrated that transgenic plants can be used to produce high affinity, monoclonal secretory antibodies that can prevent specific microbial colonization in humans.

66. Bakker H, Bardor M, Molthoff JW, Gomord V, Elbers I, Stevens LH, et al. Galactose-extended glycans ofantibodies produced by transgenic plants. Proc Natl Acad Sci U S A. 2001;98:2899-904. https://doi.org/10.1073/pnas.031419998.

67. Meager A. The molecular biology of cytokines. In: James K, Morris A, editors. Molecular Medical Science Series. London: John Wiley \& Sons; 1998.

68. Walsh G. Biopharmaceutical benchmarks. Nat Biotechnol. 2000;18:831-3.

69. Zeltins A. Construction and characterization of virus-like particles: a review. Mol Biotechnol. 2013;53:92-107. https://doi.org/ 10.1007/s12033-012-9598-4.

70. Spohn G, Bachmann MF. Exploiting viral properties for the rational design of modern vaccines. Expert Rev Vaccines. 2008;7:4354. https://doi.org/10.1586/14760584.7.1.43.

71. Mason HS, Lam DM, Arntzen CJ. Expression of hepatitis B surface antigen in transgenic plants. Proc Natl Acad Sci U S A. 1992;89:11745-9.

72. Greco R, Michel M, Guetard D, Cervantes-Gonzalez M, Pelucchi $\mathrm{N}$, Wain-Hobson S, et al. Production of recombinant HIV-1/HBV virus-like particles in Nicotiana tabacum and Arabidopsis thaliana plants for a bivalent plant-based vaccine. Vaccine. 2007;25:822840. https://doi.org/10.1016/j.vaccine.2007.09.061. This study described the successful expression of novel recombinant HIV-1/HBV virus-like particles (VLPs) in Nicotiana tabacum and Arabidopsis thaliana.

73. Thuenemann EC, Meyers AE, Verwey, Rybicki EP, Lomonossoff GP. A method for rapid production of hetero-multimeric protein complexes in plants: assembly of protective bluetongue virus-like particles. Plant Biotechnol J. 2013;11:839-46.

74. Santi L, Batchelor L, Huang Z, Hjelm B, Kilbourne J, Arntzen CJ, et al. An efficient plant viral expression system generating orally immunogenic Norwalk virus-like particles. Vaccine. 2008;26: 1846-54. https://doi.org/10.1016/j.vaccine.2008.01.053.

75. Lai H, He J, Engle M, Diamond MS, Chen Q. Robust production of virus-like particles and monoclonal antibodies with geminiviral replicon vectors in lettuce. Plant Biotechnol J. 2012;10:95-104. https://doi.org/10.1111/j.1467-7652.2011.00649.x.

76. Vz-ina L-P, D - aoust M-A, Landry N, Couture MMJ, Charland N, Ors F, Barbeau B, Sheldon AJ. Plants as an innovative and accelerated vaccine-manufacturing solution: a plant-based expression system could provide greater speed and capacity than other recombinant technologies at a comparatively low cost. Bio Pharm Int. 2011;24:S27-S30.

77. Scotti N, Rybicki EP. Plant-produced virus-like particle vaccines. In: Buonaguro FM, Buonaguro L, editors. Virus-like particles in vaccine development. London: Future Medicine Ltd.; 2014. p. $102-18$.

78. Wu J, Yu L, Li L, Hu J, Zhou J, Zhou X. Oral immunization with transgenic rice seeds expressing VP2 protein of infectious bursal disease virus induces protective immune responses in chickens. Plant Biotechnol J. 2007;5:570-8. https://doi.org/10.1111/j.14677652.2007.00270.x.

79. Gomez E, Lucero MS, Chimeno Zoth S, Carballeda JM, Gravisaco MJ, Berinstein A. Transient expression of VP2 in Nicotiana benthamiana and its use as a plant-based vaccine against infectious bursal disease virus. Vaccine. 2013;31:26237. https://doi.org/10.1016/j.vaccine.2013.03.064.

80. Vermij P. USDA approves the first plant-based vaccine. Nat Biotechnol. 2006;24:233-4.

81. Joensuu JJ, Niklander-Teeri V, Brandle JE. Transgenic plants for animal health: plant-made vaccine antigens for animal infectious disease control. Phytochem Rev. 2008;7:553-77.

82. Joensuu JJ, Kotiaho M, Teeri TH, Valmu L, Nuutila AM, Oksman-Caldentey KM, et al. Glycosylated F4 (K88) fimbrial adhesin FaeG expressed in barley endosperm induces ETECneutralizing antibodies in mice. Transgenic Res. 2006;15:35973. https://doi.org/10.1007/s11248-006-0010-7.

83. Kolotilin I, Kaldis A, Devriendt B, Joensuu J, Cox E, Menassa R. Production of a subunit vaccine candidate against porcine postweaning diarrhea in high-biomass transplastomic tobacco. PLoSOne. 2012;7:e42405. https://doi.org/10.1371/journal.pone. 0042405.

84. Joensuu JJ, Verdonck F, Ehrstrom A, Peltola M, Siljander-Rasi H, Nuutila AM, et al. F4 (K88) fimbrial adhesin FaeG expressed in alfalfa reduces F4+ enterotoxigenic Escherichia coli excretion in weaned piglets. Vaccine. 2006;24:2387-94. https://doi.org/10. 1016/j.vaccine.2005.11.056.

85. Lamphear BJ, Jilka JM, Kesl L, Welter M, Howard JA, Streatfield SJ. A corn-based delivery system for animal vaccines: an oral transmissible gastroenteritis virus vaccine boosts lactogenic immunity in swine. Vaccine. 2004;22:2420-4. https://doi.org/10. 1016/j.vaccine.2003.11.066.

86. Yang CD, Liao JT, Lai CY, Jong MH, Liang CM, Lin YL, et al. Induction of protective immunity in swine by recombinant bamboo mosaic virus expressing foot-and-mouth disease virus 
epitopes. BMC Biotechnol. 2007;7:62. https://doi.org/10.1186/ 1472-6750-7-62.

87. Khandelwal A, Lakshmi Sita G, Shaila MS. Oral immunization of cattle with hemagglutinin protein of rinderpest virus expressed in transgenic peanut induces specific immune responses. Vaccine. 2003;21:3282-9.

88. Perez Filgueira DM, Zamorano PI, Dominguez MG, Taboga O, Del Medico Zajac MP, Puntel M, et al. Bovine herpes virus gD protein produced in plants using a recombinant tobacco mosaic virus (TMV) vector possesses authentic antigenicity. Vaccine. 2003;21:4201-9.

89. Aguirreburualde MS, Gomez MC, Ostachuk A, Wolman F, Albanesi G, Pecora A, et al. Efficacy of a BVDV subunit vaccine produced in alfalfa transgenic plants. Vet Immunol Immunopathol. 2013;151:315-24. https://doi.org/10.1016/j. vetimm.2012.12.004.

90. Yang D, Kim H, Lee K, Song J. The present and future of rabies vaccine in animals. Clin Exp Vaccine Res. 2013;2:19-25. https:// doi.org/10.7774/cevr.2013.2.1.19.

91. Loza-Rubio E, Nadin-Davis SA, Morales SE. Molecular and biological properties of rabies viruses circulating in Mexican skunks: focus on $\mathrm{P}$ gene variation. Revista Mexicana de Ciencias Pecuarias. 2012a;3:155-70.

92. Van Dolleweerd CJ, Teh AY, Banyard AC, Both L, Lotter-Stark $\mathrm{HC}$, Tsekoa T, et al. Engineering, expression in transgenic plants and characterisation of E559, a rabies virus-neutralising monoclonal antibody. J Infect Dis. 2014;210:200-8.

93. Loza-Rubio E, Rojas-A E, Lopez J, Olivera-Flores MT, Gómez-L M, Tapia-Perez G. Induction of a protective immune response to rabies virus in sheep after oral immunization with transgenic maize, expressing the rabies virus glycoprotein. Vaccine. 2012b;30:5551-6. This study report the efficacy of an edible vaccine against rabies evaluated in sheep. This is the first study in which an orally administered edible vaccine showed efficacy in a polygastric model.

94. Melnik S, Stoger E. Green factories for biopharmaceuticals. Curr Med Chem. 2013;20:1038-46.
95. Qiu X, Wong G, Audet J, Bello A, Fernando L, Alimonti JB, et al. Reversion of advanced Ebola virus disease in nonhuman primates with ZMapp. Nature. 2014;514:47-53. https://doi.org/10.1038/ nature 13777.

96. Zimmermann J, Saalbach I, Jahn D, Giersberg M, Haehnel S, Wedel J, et al. Antibody expressing pea seeds as fodder for prevention of gastrointestinal parasitic infections in chickens. BMC Biotechnol. 2009;9:79. https://doi.org/10.1186/1472-6750-9-79.

97. Virdi V, Coddens A, De Buck S, Millet S, Goddeeris BM, Cox E, et al. Orally fed seeds producing designer IgAs protect weaned piglets against enterotoxigenic Escherichia coli infection. Proc Natl Acad Sci U SA. 2013;110:11809-14.

98. Ma JK, Hiatt A, Hein M, Vine ND, Wang F, Stabila P, et al. Generation and assembly of secretory antibodies in plants. Science. 1995;268:716-9.

99. Pastagia M, Schuch R, Fischetti VA, Huang DB. Lysins: the arrival of pathogen-directed anti-infectives. J Med Microbiol. 2013;62:1506-16. https://doi.org/10.1099/jmm.0.061028-0.

100. Oey M, Lohse M, Scharff LB, Kreikemeyer B, Bock R. Plastid production of protein antibiotics against pneumonia via a new strategy for high-level expression of antimicrobial proteins. Proc Natl Acad Sci U SA. 2009;106:6579-84.

101. Zeitler B, Bernhard A, Meyer H, Sattler M, Koop HU, Lindermayr C. Production of a de-novo designed antimicrobial peptide in Nicotiana benthamiana. Plant Mol Biol. 2013;81:259-72. https:// doi.org/10.1007/s11103-012-9996-9.

102. Lee SB, Li B, Jin S, Daniell H. Expression and characterization of antimicrobial peptides Retrocyclin-101 and Protegrin-1 in chloroplasts to control viral and bacterial infections. Plant Biotechnol J. 2011;9:100-15. https://doi.org/10.1111/j.1467-7652.2010.00538. $\mathrm{x}$.

103. Company N, Nadal A, La Paz JL, Martinez S, Rasche S, Schillberg S, et al. The production of recombinant cationic alpha-helical antimicrobial peptides in plant cells induces the formation of protein bodies derived from the endoplasmic reticulum. Plant BiotechnolJ. 2014;12:81-92. https://doi.org/10.1111/pbi. 12119 . 